Original Research

\title{
Family Coping Strategies to Improve the Health of Family Members Living with Schizophrenia
}

\author{
Sugeng Mashudi ${ }^{1}$ and Ah Yusuf ${ }^{2}$ \\ 1 Universitas Muhammadiyah Ponorogo, East Java, Indonesia \\ 2 Faculty of Nursing, Universitas Airlangga, Surabaya, Indonesia
}

\begin{abstract}
Introduction: Schizophrenia is a serious mental illness that affects the thinking, emotions, relationships, and decision-making. One of the positive effects of treating schizophrenia in patients is family health. The family welfare management strategies provide help for coping, care preparation, organizing meetings, and mentoring. This study focuses on family coping strategies for improving the health of members living with schizophrenia.
\end{abstract}

Methods: A cross-sectional design was used by choosing 160 respondents randomly. The inclusion criteria were family members accompanying control schizophrenia patients to the Public Health Center, with a minimum age of 18. The independent variable was family coping, which consist of two subvariables (problem-focused coping mechanism and emotion-focused coping mechanism), while the dependent variable was family health, which consists of three sub-variables (efficient, satisfaction, and happiness). The SMART PLS (2.0 Version) was used to prove the impact of the variables.

Results: The results indicated that family coping had a significant impact on the health of the family. The hypothesis was taken from the value of the T-test on the structural model analysis, which shows T- statistics (13.966) > Tcritical (1.96). The impact of family coping on the health is equal to 0.682 (OR). This means that if family coping is given one-unit value, it will increase the family health by 0.682 times.

Conclusion: The implementation of the family coping strategy will improve the capacity of the family to clarify health issues encountered, resolve family behaviors effectively and minimize risk factors. Furthermore, the coping mechanisms chosen by families in facing stress will have an impact on the reduction of illness symptoms in the members with schizophrenia.

\section{ARTICLE HISTORY}

Received: January 12, 2021

Accepted: April 13, 2021

\section{KEYWORDS}

family coping; family health; positive outcomes; schizophrenia

\section{CONTACT}

Sugeng Mashudi

$\bowtie$ sugengmashudi@umpo.ac.id

$\equiv$ Universitas Muhammadiyah

Ponorogo, East Java, Indonesia

Cite this as: Mashudi, S., \& Yusuf, A. (2021). Family Coping Strategies to Improve the Health of Family Members Living with Schizophrenia. Jurnal Ners, 16(1). 67-73. doi:http://dx.doi.org/10.20473/in.v16i1.24527

\section{INTRODUCTION}

Family caregivers are an important aspect of caring for people with serious mental illnesses, but the needs of those who do it are often not met (YesufuUdechuku et al., 2015). Furthermore, the family caregivers who support patients with psychosis frequently have poorer health (Sin et al., 2021). Treating a schizophrenic patient is a source of stress for the family, and there may be external or internal criticism before it affects the family (Byba Melda Suhita, Prima Dewi Kusumawati, \& Heri Saputro, 2020). Caring for a patient with mental illness creates a wide range of issues that place a significant burden on family caregivers (Ebrahimi et al., 2018). The data obtained from the Institute for Health Metrics and Evaluation (IHME) show that schizophrenic disorders affect about 1.5 million individuals (0.3\%) (OECD/European Union, 2018); 1\% of the population in the United Kingdom are also experiencing mental disorders (Smith, 2015). The 2018 RISKESDAS (Basic Health Research) data in Indonesia show an escalation of proportion in the number of households with mental disorders by 7 per mil from 1.7 per mil. Specifically, the East Java Province shows that only 2.2 per mil households experienced mental disorders in 2013 but increased to 5 per mil in 2018 (Riskesdas, 2018). Generally, similar incident rate also occurred 
in Ponorogo, with about 1,321 out of $600 \mathrm{~m} 336$ residents in productive ages experiencing mental disorders (Nasriati, 2017). However, a higher prevalence rate was found in Paringan Village and Dukuh Mirah, where the prevalence rate of mental disorders in Paringan Village was at 11.2 per mil (Mashudi \& Widiyahseno, 2016). Decreased family health has effects on patients and relatives.

Various causes of decreased family health of people with schizophrenia include those from within and outside the family. The complexity of the health service system (Gear et al., 2018). and the complexity of the treatment program (Murugappan et al., 2020), are factors that cause poor family health that comes from factors outside the family. Decision-making conflicts (Hamann \& Heres, 2019), economic difficulties (Marazziti et al., 2020), and family conflicts (Plessis, Golay, Wilquin, Favrod, \& Rexhaj, 2018), are external factors in decreasing family health.

Various ways are used to improve family health, including family coping support (Rayes et al., 2021). care planning support (Nyman et al., 2020), coordinated family discussions (Storm et al., 2020), and family mentoring (Andersen et al., 2020). Based on the family health theory, family coping support is very effective in improving family health (Doornbos, 2002). Furthermore, coping is described as the method of balancing external or internal demands that are perceived to be taxing or exceeding the person's resources, it may be problem-focused or emotion-focused (Grover, Pradyumna, \& Chakrabarti, 2015). Choosing the best coping strategy increases mental health (O'Hara et al., 2019). Increases in problem-focused coping were associated with higher levels of wellbeing (De Vibe et al., 2018). There is little research examining family coping in the context of family health.

If an unhealthy caregiver is not treated immediately, it can affect people with schizophrenia. Emotions of family caregivers that often increase will have an impact on increasing the recurrence of schizophrenics (Pardede, Sirait, Riandi, Emanuel, \& Ruslan, 2016). Therefore, the optimal caregiver health will support the rehabilitation of people with schizophrenia. Schizophrenics receiving occupational therapy are more appreciated by their families (Sugeng Mashudi et al., 2020).

Studies on the positive outcomes of treating schizophrenia in Indonesia are still rare and one of the positive outcomes of schizophrenia in patients is family health, which is influenced by coping mechanisms (Doornbos, 2007). Study conducted by Çuhadar, Savaş, Ünal, and Gökpınar (2015) strengthens the previous studies, which reported that coping mechanism affects family health. The studies regarding stress and coping mechanisms in family with schizophrenic members show that there is an effect of stress on coping mechanisms (Geriani et al., 2015). Family coping consists of problem-focused coping and emotion-focused coping. Furthermore, it is a cognitive assessment and behavior to manage internal and external needs that exceed ability (Lazarus \& Folkman, 1984). The study carried out by Crowe and Lyness (2014) shows that family coping affects family health. A better family coping will increase the level of family health. This study focuses on family coping strategies to improve the family health people living with schizophrenia.

\section{MATERIALS AND METHODS}

This study was conducted in Ponorogo Regency, East Java, Indonesia, with a sample of 160 respondents and a cross-sectional design. The data were collected through questionnaires, and the validity and reliability was tested. The respondents were selected by using a random sampling technique from five primary healthcare centers in the North and West Ponorogo. The inclusion criteria included: 1) family members accompanying control schizophrenia patients to the Public Health Center, 2) at least 18 years old. The exclusion criteria included: 1) caregiver suffering from psychiatric or physical disorders that may interfere with patient care and cooperation during data collection, 2) there is more than one schizophrenic patient in the family. Families with schizophrenia that visit the health center according to the inclusion and exclusion criteria that have an odd number are targeted as research respondents. After completing the informed consent of the schizophrenic family of people that filled out the questionnaire prepared by the researcher, after the questionnaire was filled in and submitted to the researcher, the completeness of the answers was checked, if the answers were complete, then as a sign of anchovies, the researcher gave a gift to respondents.

Gender, age, marital status, education, number of family members, occupation, and income are all demographic variables. Family coping variables were compiled based on the Family Coping Questionnaire (FCQ). FCQ is a questionnaire to measure family coping based on Plessis et al. (2018), which has been modified into Indonesian. There are two components, namely the problem of focus coping and emotional focus coping with seven questions. I speak in a harsh or dirty tone to the patient; I will take care of the patient carefully; I share problems about the sufferer's condition with friends/relatives; I get help from people around me; I leave the house temporarily when the patient gets angry; I think of letting the patient suffer a relapse; I think to pray more in such a way that the patient's condition is better. In positive questions, always scores 4 , often 3 , rarely 2 , and never 1 , while in negative questions always scores 1 , often 2 , rarely 3 , and never 4 . A higher score reflects better family coping. The Cronbach's alpha coefficient for the scale was 0.534 .

Family health variables were created based on the indicators of useful, satisfaction, and happiness. The useful questionnaires are arranged based on family assignments (Susanto, Arisandi, Kumakura, Oda, Koike, Tsuda, \& Sugama, 2018). There are five 
questions: 1) the family is able to know the patient's health problem; 2) the family is able to decide the best course of action for the patient; 3 ) the family is able to care for the patient well; 4) the family is able to maintain a conducive environment; 5) the family is able to use health facilities for the patient. Each positive item is scored using a 4-point scale (4= always, 3= often, 2= rarely, $1=$ ever), while for negative questions always scores 1 , often 2 , rarely 3 , and never 4 . Satisfaction is measured based on the APGAR family (Takenaka \& Ban, 2016). There are four questions, namely: 1) I feel satisfied because my family can adjust to the patient; 2) I feel satisfied because my family is discussing the best solution to solve the problems that befell the patient; 3) I am satisfied because my family shows compassion and responds to patient emotions, such as feelings of anger, suffering, and compassion; 4) I feel satisfied with my family's way of spending time together by involving patient in overcoming problems. The respondents' answers are scored always 4, often 3, rarely 2 , and never 1 .

The happy indicator is measured based on the Happy Questionnaire (Spears, 2017), with three questions, namely: 1) overall my family feels happy; 2) compared to the family of fellow caregivers with schizophrenia, my family feels happier; 3) the caregiver family with schizophrenia feels happy. They enjoy whatever is going on and get the most out of nurturing. The respondents' answers are scored always 4 , often 3 , rarely 2 , and never 1 . A higher score reflects better family health. The Cronbach's alpha coefficient for the scale was 0.883 .

Before the statistical analysis, the data were selected based on three standard deviations above or below the average score. Missing values are excluded from the analysis. Descriptive statistics for demographic variables were performed with the SPSS program (Version 22.0, IBM Corp, Armonk, NY, USA). Family coping and family health variables were performed with structural equation models and tested with Mplus (Version 7.4, Muthen \& Muthen, Los Angeles, CA, USA). The study of the structural model with a corrected level of confidence (CI) of 95\% used 5000 bootstrap samples.

\section{RESULTS}

The data used in this study were taken from 160 families of schizophrenia patients who seek treatments in primary healthcare centers located in the North and West Ponorogo. Selected respondents were those who met the criteria of random sampling.

The observation of the study was done in the selected primary healthcare centers. The complete characteristics of caregivers who handle schizophrenia patients can be seen in Table 1 .

Table 1 shows that the majority of caregivers are 81 men (50.6\%) and 79 women (49.4\%). Their average age was 49 (SD = 14.2). Furthermore, 139 respondents are married (86.6\%) and 10 single respondents (6.3\%). Regarding education level, 102 respondents have completed basic education (24.4\%), 39 respondents have achieved secondary education (48.68\%), and three respondents have completed tertiary education (1.9\%). They worked as farmers $(56.2 \%)$ with $>3$ family members (54.4\%) and salary less than IDR 1,500,000 (82.5\%).

Table 2 explains that the majority of schizophrenia patients are men (59.6\%) in the age of 17-45 (81.9\%), and siblings of the caregivers (51.8\%). The majority of schizophrenics in productive age tend to behave in smoking, even though the effects of nicotine contained in cigarettes affect oocyte maturity (Dwirahayu \& Mashudi, 2016).

Table 3 illustrates those coping mechanisms done by the family are dominantly problem-focused coping $(\lambda=0.915)$, whereas family health is determined by the satisfaction level in treating schizophrenia patients $(\lambda=0.914)$. Coping mechanisms have an effect on family health ( $\alpha=0.05$; t-statistics $=14.393)$.

Table 1. Characteristics of Family Members Living with Schizophrenia in Ponorogo, East Java, Indonesia.

\begin{tabular}{|c|c|c|}
\hline Characteristics & $\mathbf{n}$ & $\%$ \\
\hline \multicolumn{3}{|l|}{ Gender } \\
\hline Men & 81 & 50.6 \\
\hline Women & 79 & 49.4 \\
\hline \multicolumn{3}{|l|}{$\begin{array}{l}\text { Age (based on central bureau of } \\
\text { statistics Republic of Indonesia): }\end{array}$} \\
\hline Productive (18-54) & 102 & 63.8 \\
\hline Not productive (55-80) & 58 & 36.2 \\
\hline \multicolumn{3}{|l|}{ Status: } \\
\hline Married & 139 & 86.8 \\
\hline Single & 10 & 6.3 \\
\hline Widower/widow & 11 & 6.9 \\
\hline \multicolumn{3}{|l|}{ Education } \\
\hline High (Senior High School) & 76 & 74.5 \\
\hline $\begin{array}{l}\text { Low (Elementary School, Junior } \\
\text { High School) }\end{array}$ & 84 & 52.5 \\
\hline \multicolumn{3}{|l|}{ Job } \\
\hline Private & 47 & 29.4 \\
\hline Farmer & 90 & 56.2 \\
\hline Others & 23 & 14.4 \\
\hline \multicolumn{3}{|l|}{ Family members (number) } \\
\hline$\leq 3$ & 73 & 45.6 \\
\hline$>3$ & 87 & 54.4 \\
\hline \multicolumn{3}{|l|}{$\begin{array}{l}\text { Salary (regional minimum wage in } \\
\text { Ponorogo, Indonesia) }\end{array}$} \\
\hline$<$ IDR $1,500,000$ & 132 & 82.5 \\
\hline$\geq \operatorname{IDR} 1,500,000$ & 28 & 17.5 \\
\hline
\end{tabular}

Table 2: Characteristics of Schizophrenia Patients

\begin{tabular}{lcc}
\hline \multicolumn{1}{c}{ Characteristics } & $\mathbf{n}$ & $\mathbf{\%}$ \\
\hline Gender & & \\
$\quad$ Men & 95 & 59.6 \\
$\quad$ Women & 65 & 40.4 \\
Age & & \\
$\quad$ Productive (17-45) & 131 & 81.9 \\
$\quad$ Not productive (46-71) & 29 & 18.1 \\
Relationship with caregiver: & & \\
$\quad$ Son/Daughter & 63 & 39.4 \\
$\quad$ Parent & 14 & 8.8 \\
Others (Siblings) & 83 & 51.8 \\
\hline
\end{tabular}


Table 3: Loading Factors and T-statistical Value.

\begin{tabular}{|c|c|c|c|}
\hline Variables & Loading $(\lambda)$ & T-Statistics & T-table \\
\hline \multicolumn{4}{|l|}{ Coping Mechanisms } \\
\hline Problem-focused Coping & 0.915 & & \\
\hline Emotion-focused Coping & 0.710 & 14.393 & 1.96 \\
\hline \multicolumn{4}{|l|}{ Family Health } \\
\hline Useful & 0.912 & & \\
\hline Satisfaction & 0.914 & & \\
\hline Happiness & 0.873 & & \\
\hline
\end{tabular}

\section{DISCUSSION}

Family coping significantly impacts family health. This is based on the T-test in the structural model analysis, where T-statistics (13.966) is greater than Tcritical (1.96). The effect value of coping mechanisms on family health is 0.682 . This means that if family coping is given one-unit value, it will increase family health by 0.682 times.

Family health is measured from the aspects of useful, satisfaction, and happiness. Useful shown by the family may include knowing health problems experienced by patients, choosing the best action to treat patients, maintaining a conducive environment, and utilizing health facilities for patients. Useful indicator (0.912) has the second-highest value in determining family health. Useful throughout the treatment process can be seen when a family could identify patients' health problems, decide the best decision for them, take care of them well, keep a conducive environment, and take advantages of health facilities for the family.

As many as $64.4 \%$ of families are satisfied in caring for family members who have schizophrenia. Satisfaction is shown as the family stated that family satisfaction with schizophrenia patient care may be obtained by adapting with patients, discussing the best solution to overcome problems that befall patients, showing affections and responses, such as anger, suffering, and love, and spending time together with patients. The satisfaction indicator (0.914) possesses the highest value in determining family health. Satisfaction throughout the treatment process can be found when a family can adapt, choose the best solution for problems, show affection, respond positively to patients, and spend some time together with patients. Family satisfaction in treating schizophrenia patients cannot be separated from the impact of coping mechanisms (problem-focused coping and emotion-focused coping) done by the family.

Happiness is shown as the family could enjoy the moment of treating patients with schizophrenia compared to other caregivers with schizophrenia patients. Also, they could enjoy everything and obtain optimal treatment for schizophrenia patients. The happiness indicator $(0.873)$ shows the smallest value in determining family health. The decline of happiness in treating schizophrenia patients can be seen when family feels less happy compared to other families with schizophrenia patients and cannot enjoy everything and obtain optimal caregiving. It is related to stress factors, such as the economy, abusive behavior, and stigma that befalls the family. Despite the fact that parents reported being depressed as a result of prejudice, the effects of discrimination have no relationship to their depressive symptoms (Cecilia Ayo'n \& Bermudez-Parsai, 2010).

Authors should explore the family health of the respondents, how the culture or finding explain efficiency, satisfaction and happiness, before comparing it with other research; authors could define the real condition in the study setting and finding

Being healthy is defined as an ability to adapt physically, mentally, and socially as a single unit free from illness and disability (WHO, 1948). The characteristics of being healthy according to WHO involve the ability to reflect an individual as a person in internal and external contexts and to involve creativity and productivity. King (1981) stated that being healthy is a form of efficiency, satisfaction, productivity, and happiness (Alligood, 2017). In this study, family health refers to a healthy family (King, 1981). However, the productivity indicator in this study is invalid and unreliable because the submitted questions only focus on attendance, while the respondents of the study are farmers who were unable to attend regularly.

The essential finding of this study is that family coping affects family health. Family Health Theory by Doornbos (2002) shows that coping mechanisms affect family health, whereas this study, in addition to the existing theory, finds family health indicator was measured not only based on family satisfaction, but also family efficiency and happiness. Coping mechanisms chosen by families in facing stress will impact family health (Martínez-Montilla et al., 2017). Caregiver burden had positive correlation with age of caregiver, employment of caregiver and level of education (S Mashudi et al., 2019).

Family coping was related to increased family health in those with impaired attentional function (Morimoto, Furuta, \& Kono, 2019). Coping was linked to increased psychological pressure in people who had poor attention management (Tada, 2017). Family coping and family health benefit from compassionate counseling (Buckley, Maayan, \& Soares-Weiser, 2017). Antonovsky's sense of coherence influences coping, resulting in increased family happiness (Gassmann et al., 2013). Stress may come from 
chronic diseases, such as mental disorders (schizophrenia), addictions, accidents, disabilities, and economic problems. On the other hand, family coping used by families in treating schizophrenia patients are problem-focused coping and emotionfocused coping. Stress in a family with schizophrenia patients can transform the family's life balance. That is why every family needs to have good coping strategies. Caregivers with patients who have mental disorders also need to identify the main stress factor in their family. The best coping strategy is also needed so that family health can improve. Based on the theoretical and empirical studies, it can be inferred that family coping affects family health.

Family coping strategies include observation, counseling, education and cooperation. (PPNI, 2017). An emotional reaction needs to be defined by the nurse (Caqueo-Urízar et al., 2017), Prognosis strain (Fusar-Poli et al., 2020), decision-making (Mandarelli et al., 2018) and expectations of family and family (Knight et al., 2018). Applying the family coping strategy may improve the capacity of the family to clarify experienced health issues, family practices to better resolve health problems, and minimize risk factors. The implementation of family coping can have an impact on reducing the symptoms of disease in family members.

\section{CONCLUSION}

This research strengthens the family health theory, and the coping mechanisms carried out by families (problem-focused coping and emotion-focused coping) affect family health. In addition to family satisfaction, the family health can also be measured in terms of useful and happiness. Additional research in needed to find out if patients and treatment factors contribute to family health.

\section{REFERENCES}

Alligood, M. R. (2017). Imogene M.King: Sistem Konseptual dan Teori Middle-Range Pencapaian Tujuan (Model Konseptual Keperawatan). In Pakar Teori Keperawatan dan Karya Mereka (Edisi Bahasa Indonesia) (pp. 30-51). Elsevier Ltd.

Andersen, I., Poudyal, B., Abeypala, A., Uriarte, C., \& Rossi, R. (2020). Mental health and psychosocial support for families of missing persons in Sri Lanka: A retrospective cohort study. Conflict and Health, 14(1), 1-15. https://doi.org/10.1186/s13031-020-00266-0

Buckley LA, Maayan N, Soares-Weiser K, A. C. (2017). Supportive therapy for schizophrenia (Review). Cochrane Database of Systematic Reviews, 4. https://doi.org/10.1002/14651858.CD004716.p ub4.www.cochranelibrary.com

Byba Melda Suhita, Prima Dewi Kusumawati, Heri Saputro, A. Y. (2020). Mechanism of Family-coping in Treating Patient with Schizophrenia Viewed from Factors that Affected it at Public Health Center of Balowerti, Kediri. Medico Legal Update, $20(1)$.
Caqueo-urízar, A., Rus-calafell, M., Craig, T. K. J., Irarrazaval, M., Urzúa, A., Boyer, L., Williams, D. R., \& Rus-calafell, M. (2017). Schizophrenia : Impact on Family Dynamics. Current Psychiatry Reports, 19(2). https://doi.org/10.1007/s11920-0170756-z

Cecilia Ayo' n, F. F. M., \& Bermudez-Parsai, and M. (2010). LATINO FAMILY MENTAL HEALTH: EXPLORING THE ROLE OF DISCRIMINATION AND FAMILISMO. Journal of Community Psychology, 38(6), 742-756.

De Vibe, M., Solhaug, I., Rosenvinge, J. H., Tyssen, R., Hanley, A., \& Garland, E. (2018). Six-year positive effects of a mindfulness-based intervention on mindfulness, coping and well-being in medical and psychology students; Results from a randomized controlled trial. PLoS ONE, 13(4), 1-17. https://doi.org/10.1371/journal.pone.0196053

Doornbos. (2007). Family Health Theory. In C. L. Sieloff \& M. A.Frey (Eds.), Middle Range Theory Development Using King's Conceptual Systemy (pp. 31-49). Springer Publishing Company, Inc.

Doornbos MM. (2002). Predicting family health in families of young adults with severe mental illness. Journal of Family Nursing, 8(3), 241-263.

Ebrahimi, H., Seyedfatemi, N., Namdar Areshtanab, H., Ranjbar, F., Thornicroft, G., Whitehead, B., \& Rahmani, F. (2018). Barriers to Family Caregivers' Coping With Patients With Severe Mental Illness in Iran. Qualitative Health Research, 28(6), 9871001. https://doi.org/10.1177/1049732318758644

Fusar-Poli, P., de Pablo, G. S., Correll, C. U., MeyerLindenberg, A., Millan, M. J., Borgwardt, S., Galderisi, S., Bechdolf, A., Pfennig, A., \& Kessing, L. V. (2020). Prevention of psychosis: advances in detection, prognosis, and intervention. JAMA Psychiatry.

Gassmann, W., Christ, O., Lampert, J., \& Berger, H. (2013). The influence of Antonovsky's sense of coherence (SOC) and psychoeducational family intervention (PEFI) on schizophrenic outpatients' perceived quality of life: A longitudinal field study. BMC Psychiatry, 13, 2-7. https://doi.org/10.1186/1471-244X-13-10

Gear, C., Eppel, E., \& Koziol-Mclain, J. (2018). Exploring the complex pathway of the primary health care response to intimate partner violence in New Zealand. Health Research Policy and Systems, 16(1), 1-13. https://doi.org/10.1186/s12961-018-0373-2

Geriani, D., Savithry, K. S. B., Shivakumar, S., \& Kanchan, T. (2015). Burden of care on caregivers of schizophrenia patients: A correlation to personality and coping. Journal of Clinical and Diagnostic Research, 9(3), VC01-VC04. https://doi.org/10.7860/JCDR/2015/11342.565 4

Grover, S., Pradyumna, \& Chakrabarti, S. (2015). Coping among the caregivers of patients with schizophrenia. Industrial Psychiatry Journal, 24(1),

5-11. 
https://doi.org/https://doi.org/10.4103/09726748.160907

Hamann, J., \& Heres, S. (2019). Why and how family caregivers should participate in shared decision making in mental health. Psychiatric Services, $70(5)$, 418-421. https://doi.org/10.1176/appi.ps.201800362

King, I. M. (1981). A theory for nursing: System, concepts, pocess. Delmar.

Knight, F., Kokanović, R., Ridge, D., Brophy, L., Hill, N., Johnston-Ataata, K., \& Herrman, H. (2018). Supported decision-making: the expectations held by people with experience of mental illness. Qualitative Health Research, 28(6), 1002-1015.

Lea Plessis , Philippe Golay , H' el ' ene Wilquin , J ' er' ome Favrod, ^, \& Rexhaj, S. (2018). Internal validity of the French version of the Family Coping Questionnaire (FCQ): A confirmatory factor analysis. Psychiatry Research. https://doi.org/https://doi.org/10.1016/j.psych res.2018.08.021

Mandarelli, G., Carabellese, F., Parmigiani, G., Bernardini, F., Pauselli, L., Quartesan, R., Catanesi, R., \& Ferracuti, S. (2018). Treatment decisionmaking capacity in non-consensual psychiatric treatment: a multicentre study. Epidemiology and Psychiatric Sciences, 27(5), 492-499.

Marazziti, D., Avella, M. T., Mucci, N., Della Vecchia, A., Ivaldi, T., Palermo, S., \& Mucci, F. (2020). Impact of economic crisis on mental health: A 10-year challenge. CNS Spectrums, 1-7. https://doi.org/10.1017/S1092852920000140

Martínez-montilla, J. M., Amador-marín, B., \& Guerramartín, M. D. (2017). Estrategias de afrontamiento familiar y repercusiones en la salud familiar : Una revisión de la literatura Family coping strategies and impacts on family health : A literature review ABSTRACT : Revista Trimestral de Enfermeria, 47, 576-591.

https://doi.org/10.6018/eglobal.16.3.255721

Mashudi, Widiyahseno, P. (2016). Grand Design Mad Village Ponorogo (Sugeng Mas). UM POnorogo Press.

Mashudi, S, Yusuf, A., Triyoga, R. S., Kusnanto, \& Suhron, M. (2019). The burden in providing caregiving service to mentally illed patients in Ponorogo. Indian Journal of Public Health Research and Development, 10(10), 1070-1074. https://doi.org/10.5958/09765506.2019.02967.X

Mashudi, Sugeng, Nasriati, R., \& Octaviani, E. (2020). Terapi Okupasi Sebagai Sarana Peningkatan Kesehatan Jiwa Penderita Skizofrenia. Jurnal Abdidas, 1(5), 313-317. https://doi.org/10.31004/abdidas.v1i5.62

Morimoto H, Furuta N, Kono M, K. M. (2019). Stressbuffering Effect of Coping Strategies on Interrole Conflict among Family Caregivers of People with Dementia. Clin Gerontol, 42(1), 34-46. https://doi.org/10.1080/07317115.2017.13687 64. Epub 2017 Oct 9. PMID: 28990875
Murugappan, M. N., Seifert, R. D., \& Farley, J. F. (2020). Examining Medicare Part D Medication Therapy Management program in the context of mental health. Journal of the American Pharmacists Association, 60(4), 571-579.e1. https://doi.org/10.1016/j.japh.2019.12.008

Nasriati, R. (2017). Stigma and Family Support in Caring for People With Mental Disorders (ODGJ). Jurnal Ilmiah Ilmu - Ilmu Kesehatan, XV(1), 56-65. Nyman, M., Hofvander, B., Nilsson, T., \& Wijk, H. (2020). Mental Health Nurses' Experiences of Risk Assessments for Care Planning in Forensic Psychiatry. International Journal of Forensic Mental Health, 19(2), 103-113. https://doi.org/10.1080/14999013.2019.16463 56

O’Hara, K. L., Sandler, I. N., Wolchik, S. A., \& Tein, J. Y. (2019). Coping in context: The effects of long-term relations between interparental conflict and coping on the development of child psychopathology following parental divorce. Development and Psychopathology, 31(5), 16951713.

https://doi.org/10.1017/S0954579419000981

OECD/European Union. (2018). "Promoting mental health in Europe: Why and how?", in Health at a Glance: Europe 2018: State of Health in the EU Cycle,. In Health at a Glance: Europe 2018 State of Health in the EU Cycle (pp. 19-43). OECD Publishing. https://doi.org/10.1787/health_glance_eur2018-4-en

Pardede, J. K., Sirait, D., Riandi, R., Emanuel, P., Ruslan, L. (2016). EKSPRESI EMOSI KELUARGA DENGAN FREKUENSI KEKAMBUHAN PASIEN SKIZOFRENIA Emotional Expression Family With The Frequency of Recurrence of Patients With Schizophrenia. Idea Nursing Journal, VII(3), 5361.

Plessis, L., Golay, P., Wilquin, H., Favrod, J., \& Rexhaj, S. (2018). Internal validity of the French version of the Family Coping Questionnaire (FCQ): A confirmatory factor analysis. Psychiatry Research, 269 , 337-344. https://doi.org/10.1016/j.psychres.2018.08.021

PPNI. (2017). Standart Diagnosis keperawatan Indonesia: Definisi dan Indikator Diagnostik (I (cetakan). DPP PPNI.

Rayes, D., Karnouk, C., Churbaji, D., Walther, L., \& Bajbouj, M. (2021). Faith-Based Coping Among Arabic-Speaking Refugees Seeking Mental Health Services in Berlin, Germany: An Exploratory Qualitative Study. Frontiers in Psychiatry, 12(February), 1-10. https://doi.org/10.3389/fpsyt.2021.595979

Riskesdas. (2018). Healthy Portrait of Indonesia from Riskesdas 2018. Ministry of Health of the Republic of Indonesia.

S.Lazarus, R., \& Folkman, S. (1984). Stress, Appraisal and Coping. Springer Publishing Company, Inc.

Sin, J., Elkes, J., Batchelor, R., Henderson, C., Gillard, S., Woodham, L. A., Chen, T., Aden, A., \& Cornelius, V. 
(2021). Mental health and caregiving experiences of family carers supporting people with psychosis. Epidemiology and Psychiatric Sciences, 30. https://doi.org/10.1017/S2045796020001067

Smith, G. (2015). Skizophrenia. In I. Peate (Ed.), Mental Health Nursing at a Glance (First Edit, p. 34). John Wiley\&Sons, Ltd.

Spears, D. (2017). Making people happy or making happy people? Questionnaire-experimental studies of population ethics and policy. Social Choice and Welfare, 49(1), 145-169. https://doi.org/10.1007/s00355-017-1055-7

Storm, M., Fortuna, K. L., Brooks, J. M., \& Bartels, S. J. (2020). Peer Support in Coordination of Physical Health and Mental Health Services for People With Lived Experience of a Serious Mental Illness. Frontiers in Psychiatry, 11(May), 1-7. https://doi.org/10.3389/fpsyt.2020.00365

Susanto, T., Arisandi, D., Kumakura, R., Oda, A., Koike, M., Tsuda, A., Sugama, J. (2018). Development and testing of the family structure and family functions scale for parents providing adolescent reproductive health based on the Friedman family assessment model. Journal of Nursing Measurement, 26(2), 217-236. https://doi.org/10.1891/1061-3749.26.2.217

Tada, A. (2017). The associations among psychological distress, coping style, and health habits in Japanese nursing students: A crosssectional study. International Journal of Environmental Research and Public Health, 14(11). https://doi.org/10.3390/ijerph14111434

Takenaka, H., \& Ban, N. (2016). The most important question in family approach: the potential of the resolve item of the family APGAR in family medicine. Asia Pacific Family Medicine, 15(1), 3. https://doi.org/10.1186/s12930-016-0028-9 WHO. (1948). No Title. Definition of Health.

Yesufu-Udechuku, A., Harrison, B., Mayo-Wilson, E., Young, N., Woodhams, P., Shiers, D., Kuipers, E., \& Kendall, T. (2015). Interventions to improve the experience of caring for people with severe mental illness: Systematic review and meta-analysis. British Journal of Psychiatry, 206(4), 268-274. https://doi.org/10.1192/bjp.bp.114.147561 